\title{
Hepatosplenomegaly in liver cirrhosis is caused by reactive oxygen species formation, an increase in apoptosis and autophagy, and pronounced autoimmune reactions
}

\author{
E. M. Klimova*,**, L. A. Drozdova*, O. V. Lavinska****, E. A. Bychenko*,**, Y. H. Kot**, T. I. Kordon* \\ *Zaycev V. T. Institute of General and Urgent Surgery of National Academy of Medical Sciences of Ukraine, Kharkiv, Ukraine \\ **V. N. Karazin Kharkiv National University, Kharkiv, Ukraine
}

Article info

Received 29.07.2021 Received in revised form 24.08 .2021 Accepted 25.08.2021

Zaycev V.T. Institute of General and Urgent Surgery of National Academy of Medical Sciences of Ukraine, Balakireva vyizd, 1, Kharkiv, 61103, Ukraine Tel.: +38-050-172-30-33. E-mail:klimovalena53@ gmail.com

V. N. Karazin Kharkiv National University Svobody sq., 4, Kharkiv, 61022, Ukraine. Tel.: +38-050-166-71-41. E-mail: elena.lavinskava@ukr.net
Klimova, E. M., Drozdova, L. A., Lavinska, O. V., Bychenko, E. A., Kot, Y. H., \& Kordon, T. I. (2021). Hepatosplenomegaly in liver cirrhosis is caused by reactive oxygen species formation, an increase in apoptosis and autophagy, and pronounced autoimmune reactions. Regulatory Mechanisms in Biosystems, 12(3), 408-418. doi:10.15421/022156

Various factors of infectious and toxic genesis can lead to the liver cirrhosis, often accompanied by complications such as recurrent bleeding due to portal hypertension against the background of hepatosplenomegaly. Metabolic changes and disturbances in immunoreactivity occur in the liver and spleen. To substantiate the choice of personalized treatment tactics for patients with hepatosplenomegaly, we investigated individual metabolic predictors and immunopathological processes in patients with: liver cirrhosis and hepatitis B (HBV) and/or hepatitis $\mathrm{C}(\mathrm{HCV})$ viruses (I group, $\mathrm{n}=52$ ); with herpes viruses CMV (cytomegalovirus) and $\mathrm{EBV}$ (Epstein-Barr virus) (II group, $\mathrm{n}=48$ ), and with splenomegaly and frequent recurrent bleeding associated with hereditary enzymopathies (III group, $\mathrm{n}=15$ ). We used the methods of immunoturbidimetry; enzyme immunoassay; light, fluorescence and confocal microscopy. In group I (HBV/HCV), we revealed a decrease in the $\mathrm{C} 4$ component; a significant increase in the phagocytic index and phagocytic number, a reduced number of active phagocytes and the digestion index; a decrease in the IL-1 $\beta$ content and an increase in IL-18 and IL-6. In group II (CMV/EBV), we revealed a high activity of the $\mathrm{C} 3$ and a low activity of the $\mathrm{C} 4$ component against the background of a high level of ROS in neutrophils; the antineutrophil antibodies (ANCA) formation in $85.7 \%$ of patients $(71.4 \%$-perinuclear antibodies (pANCA) to myeloperoxidase; $14.3 \%$ - cytoplasmic antibodies (CANCA) to proteinase 3). Also, in group II, an increased level of pro-inflammatory cytokines IFN- $\gamma$, IL-1 $1 \beta$, TNF- $\alpha$, IL-18 and anti-inflammatory IL-6 was detected. Changes in links of immunity in II group led to the formation of autoimmune reactions in $64.7 \%$ of patients, which was expressed in the development of a broad range of antinuclear antibodies ANA (11 specificities, including ANA to chromatin and chromatin-associated proteins, to proteins cytoskeleton, enzymes and enzyme complexes). In group III, we revealed a low absorption capacity of neutrophils, a high frequency of antineutrophil antibodies pANCA occurrence and cANCA (in $67.2 \%$ of the examined), and low concentration of TNF- $\alpha$. The developed model of the stepwise change of immunological markers makes it possible to substantiate the choice of a complex targeted treatment, including antiviral and immunotropic therapy.

Keywords: hepatosplenomegaly; immunoreactivity; complement system component; phagocytic cell; autoantibodies.

\section{Introduction}

Liver cirrhosis is a clinically heterogeneous disease, and is a consequence of many causes, primarily infectious and toxic genesis (Alimova et al., 2015). The causes of the formation of complications are also heterogeneous and are the result of metabolic disorders and dysregulation of immunoreactivity in the liver, and especially in the spleen. Since the spleen performs the function of filtering the blood, it is often involved in the pathological process with liver damage (Panasiuk et al., 2003; Kanto, 2008). Particularly dangerous in clinical practice is complicated liver cirrhosis in the form of recurrent bleeding, which is caused by portal hypertension against the background of hepatosplenomegaly (Bhasin \& Malhi, 2002; Borisov \& Kashchenko, 2009).

Complicated liver cirrhosis is often a consequence of metabolic disorders affecting the exchange of amino acids, in particular, the methyl group donor L-methionine. Research has shown that in response to trigger factors that enhance oxidative reactions, there occurs deficiency of homeostatic changes in the enzyme S-adenosylmethionine synthetase (methionine adenosyltransferase (MAT) in the conditions of liver diseases of various etiologies. Suppression of synthesis of this enzyme leads to a methionine decrease in patients with cirrhosis and, in turn, correlates with a marker of oxidative stress - the level of glutathione. Methionine is a precursor of glutathione in the liver, induces many metabolic cascades, since this amino acid participates in the process of transmethylation - transfers $\mathrm{CH}_{3}$-groups to acceptors. A decrease in glutathione level indicates mitochondrial destruction due to damage of their inner membrane, followed by activation of a cytokines cascade and reactive oxygen species (ROS). Suppression of the methionine synthesis or metabolism can lead to disruption of the enzyme cystathionine beta-synthase stability, which converts homocysteine to cysteine. Pathological elevation of homocysteine is extremely unfavourable and promotes the development of inflammatory response. All these processes lead to the activation of stellate cells (SCs) that develop liver fibrosis accompanied by complications (Lieber, 2002; Lu et al., 2009; Caballero et al., 2010).

Dysfunction of the spleen leads to structural and functional changes the formation of hypersplenism or splenomegaly. The trigger factors are often viruses that have tropism for liver cells. A viral infection induces the synthesis of acute phase proteins and primarily activates natural killer cells (NK), and the synthesis of interferon. In the spleen, an active synthesis of cytokines takes place, providing intercellular signaling, the formation of complement proteins and immunoglobulins, which neutralize antigens; this can lead to the formation of small immune complexes and their depo- 
sition in the spleen and liver, and cause both acute and chronic inflammation and structural changes in the parenchymal organs (Ellmark et al., 2003; Voitsekhovsky \& Goborov, 2019).

Splenomegaly manifests in complications of many diseases of the hepatobiliary zone, since the spleen plays an active role in hematopoiesis; deposition of neutrophils, macrophages and platelets, performs the function of eliminating infectious antigens from the bloodstream. Infectious and inflammatory processes, against the background of viral persistence in patients with cirrhosis, cause the activation of spleen immune cells. The clearance of exogenous and endogenous antigens and the synthesis of antibodies increase, leading to a sharp increase in the spleen size (Elbim et al., 2008). Splenomegaly is also often included in the complex syndrome of hereditary storage diseases developing with dysfunction of lysosomal neutrophil enzymes (Zimran et al., 1990; Grechanina et al., 2004; Kolter \& Sandhoff, 2005; Simpson et al., 2014; Ferreira \& Gahl, 2017).

Infectious antigens induce the immune response in the marginal zone of the white pulp of the spleen and alter the processes of autophagy and apoptosis, induction and completion of phagocytosis by antigen-presenting cells (Fischer et al., 2007). Despite the important role of phagocytic neutrophils in the development of the immune response during infection, the participation of these cells in the pathogenesis of viral infections in patients with liver cirrhosis has been studied insufficiently.

In viral infection in patients with cirrhosis, a massive apoptotic loss of immune cells can have a negative significance, which contributes to their pre-mortal reduction (Elbim et al., 2008; Knight \& Melino, 2011). At the same time, this category of patients has incomplete processes of autophagy, apoptosis and phagocytosis against the background of increased proliferation of B and T lymphocytes in the spleen, which leads to hypersplenism. Also, a consequence of the defect in autophagy, apoptosis and phagocytosis in some patients may be an increase in the production of a wide range of autoantibodies in response to the formed antigens, and the development of autoimmune processes. The violation of immunoreactivity and immunoresistance links, and the role of the autoimmune component in patients with cirrhosis of various etiologies, complicated by hepatosplenomegaly, portal hypertension and recurrent bleeding are insufficiently studied. The study of individual metabolic predictors and the nature of immunopathological processes in patients with hepatosplenomegaly will justify the choice of personalized treatment tactics.

The objective of this study was the immunopathological reactions of innate, humoral and cellular adaptive immunity which affect the elimination, proliferative activity of cells and lead to the formation of various types of autoantibodies that cause the destruction of the protein-synthesizing apparatus in patients with viral and hereditary trigger factors for the development of cirrhosis complicated by splenomegaly.

\section{Materials and methods}

The research was carried out following the bioethical norms according to the regulations of the WHO, Helsinki Declaration of General Assembly of World Medical Association (2013), in accordance with the current ethical requirements, as confirmed by the Ethics Committee of State Institution Zaycev V. T. Institute of General and Urgent Surgery of the National Academy of Medical Sciences of Ukraine. Informed consent was received from all the subjects of blood withdrawal.

We examined 115 patients with liver cirrhosis complicated by portal hypertension, hepatosplenomegaly, and bleeding from phlebectasia. These patients were admitted urgently for treatment to the clinic of the Zaycev V. T. Institute of General and Urgent Surgery of NAMSU. In patients, the following pathogenetic hereditary and infectious trigger factors were identified: mutations in the lysosomal enzymes genes glucocerebrosidase (GBA) and chitotriosidase (CHIT1); hepatitis B (HBV) or hepatitis C (HCV), herpes virus cytomegalovirus (CMV) or Epstein-Barr virus (EBV). We composed the following groups of patients: the first (I) group included 52 patients with liver cirrhosis and hepatitis $\mathrm{B}(\mathrm{HBV})$ or hepatitis $\mathrm{C}(\mathrm{HCV})$ viruses; the duration of the disease was $2-5$ years. $\mathrm{HBsAg}$ and total anti-HCV antibodies were detected in blood serum by ELISA (upon admission to the clinic). The second (II) group included 48 patients with herpes viruses CMV (cytomegalovirus) and EBV (Epstein-Barr virus). The third (III) group included 15 patients with splenomegaly and frequent recurrent bleeding associated with hereditary enzymopathies (Gaucher's disease and others). The material for the study was blood cells and blood serum.

To study the mechanisms of metabolic disorders and immunogenetic control in chronic sensitization caused by persistent infection and enzyme mutations, we assessed changes in the immunity links involved in the inflammatory process formation and the autoimmune component in patients with splenomegaly of various etiologies. In this work, we investigated the indicators of the defense first line: acute phase proteins (C3 and C4 complement system components, IL-1 $\beta$, IL-18, IL- 6 , IFN- $\gamma$, and TNF- $\alpha$ ); oxygen-independent and oxygen-dependent phagocytosis, the intensity of apoptosis of microbial antigens by neutrophils in vitro, the intensity of ROS formation in neutrophils during oxygen-dependent phagocytosis; antinuclear antibody (ANA) and antineutronphilcytoplasmicantibodies (ANCA).

The levels of $\mathrm{C} 3$ and $\mathrm{C} 4$ complement system components were determined by the immunoturbidimetry at a wavelength $340 \mathrm{~nm}$ (StatFax 1904, USA), Dialab kits of reagents, Austria (Nilsson \& Nilsson, 2012).

Concentration of IL-1 $\beta$, IL-18, IL-6, IFN- $\gamma$, TNF- $\alpha$ in the serum was determined by solid-phase immunoassay test systems using specific monoclonal antibodies (mAbs) to IL-1 $\beta$, IL-18, IL-6, IFN- $\gamma$, TNF- $\alpha$ (VectorBest, Ukraine), sorbed on polystyrene plates, and horseradish peroxidase as an indicator enzyme. The optical density was measured at the wavelength of $450 \mathrm{~nm}$ (StatFax 3200, USA).

To determine of the phagocytosis intensity, we used three methodological approaches that allowed us to assess the stages and efficiency of oxygen-dependent and oxygen-independent phagocytosis. Use of a fluorescent label to assess the completion of antigen processing allowed us to observe the DNA denaturation stages of a microbial antigen in vitro under the action of granzyme enzymes of neutrophilic granulocytes. Oxygendependent phagocytosis was studied by two methods: 1 - the study of the effects after the ROS formation in phagolysosomes as a result of the NADP-H reaction in the NBT-test by light microscopy; 2 - visualization of the ROS formation process in organoids (lysosomes, peroxysomes, and mitochondria) of phagocytic neutrophils by confocal microscopy using fluorescent label.

The method of oxygen-independent phagocytosis using acridine orange (AO) by fluorescent microscopy (Olympus BX53, Japan) at $\times 1,000$ allowed us to analyze the digestive function of neutrophils by the degree of microbial DNA denaturation. Acridine orange monomers associated with native DNA of microorganisms were characterized by emission in the green region of the spectrum $\left(\lambda_{\max }=530 \mathrm{~nm}\right)$, while aggregates of this fluorochrome associated with denatured DNA of microorganisms changed the fluorescent colour from green to red $\left(\lambda_{\max }=640 \mathrm{~nm}\right)$. Undigested microorganisms retain the native form of their DNA, and, consequently, the green colour (Gorchakov et al., 2003). To $100 \mu \mathrm{L}$ of blood with an anticoagulant, $100 \mu \mathrm{L}$ of a suspension of microorganisms Saccharomyces cerevisiae was added, and incubated at $37^{\circ} \mathrm{C}$. After 45 minutes, $5 \mu \mathrm{L}$ of blood with a microorganisms' suspension and $5 \mu \mathrm{L}$ of AO (Yugsintez, Ukraine) solution were applied to the glass slide. The number of microbial bodies with denatured DNA absorbed by the phagocyte was counted in 100 neutrophils, which was assessed by the changed colour of the antigen from green to orange-red and red relative to yeast cells that were not digested and remained constantly intensive fluorescent green. Each stage of phagocytosis was characterized by the presence of a certain colour from bright green glow, which was observed after 15 minutes. Upon further incubation, the green fluorescence of the absorbed microorganisms changed to orange, and upon complete digestion (after $45 \mathrm{mi}$ nutes) - to red due to complete DNA denaturation. The digestion process was completed after 1.5 hours by complete lysis of the yeast. There were yeasts at different stages of digestion, since they were green and orange at the same time, inside the phagocytic cells.

The oxidation-reducing activity of neutrophils was evaluated by light microscopy (Olympus BX53, Japan) (x1000) in NBT-test (Park et al., 1968). Oxygen-dependent phagocytosis in the NBT-test in NADP-H-oxidase reactions was determined by assessing the ROS formation at the stage of phagosome in neutrophils, by the reduction of the soluble dye nitroblue tetrazolium (NBT) absorbed by the cell, generating insoluble compound diformazan under the influence of superoxide anion. The amo- 
unt of blue-violet diformazan granules in phagocytic cell reflects the activity of NADP-H-oxidase. The size of diformazan deposits was an indicator of the total activity of NADP-H-oxidase, which initiates the process of stimulation of the phagocyte. Blood with an anticoagulant $(0.05 \mathrm{~mL})$ and $0.05 \mathrm{~mL}$ of $0.2 \%$ NBT(Sigma-Aldrich, Germany) solution ( $2 \mathrm{mg}$ of dry dye was diluted in $1 \mathrm{~mL}$ of distilled water) was poured to two tubes; then put in first tube $0.05 \mathrm{~mL}$ of phosphate-buffered saline (spontaneous NBT test), in the second $-0.05 \mathrm{~mL}$ of opsonized zymosan suspension (stimulated NBT test). Opsonized zymosan was prepared by gradually diluting $100 \mathrm{mg}$ of dry zymosan (Sigma-Aldrich, Germany) in $10 \mathrm{~mL}$ of physiological saline, incubating for 40 minutes in a water bath, and further dissolving using a magnetic stirrer for 7 hours. Before the use, $0.025 \mathrm{~mL}$ of serum from donors of $\mathrm{AB}$ (IV) group and $0.025 \mathrm{~mL}$ of physiological saline were added to the zymosansuspension. It was incubated for 30 minutes, then centrifuged at $700 \mathrm{~g}$ for 10 minutes. Then we decanted the supernatant, resuspended the pellet, and added $1 \mathrm{~mL}$ of physiological saline, incubated for $30 \mathrm{~min}$ at $37^{\circ} \mathrm{C}$; centrifuged for $10 \mathrm{~min}$ at $700 \mathrm{~g}$, collected the supernatant, and resuspended the pellet. To prepare smears from the sediment, we used defatted glass slides, dried at room temperature. Fixation of smears was carried out by methyl alcohol, staining - by $0.1 \%$ solution of neutral red for 30 minutes; rinsing - by distilled water. In smear, 100 neutrophils were counted and the number of cells containing diformazan inclusions in the form of granules or solid deposits was calculated. Cells were conventionally divided into four groups: (a) - with zero activity (no granules), (b) - with a weakly positive reaction (presence of single granules), (c) - with a positive reaction (granules covered up to $50 \%$ of the cytoplasm area), (d) - with a sharply positive reaction (more than $50 \%$ of the cytoplasm area was occupied by granules). To determine the number of positive cells in the spontaneous (SP, \%) and stimulated $(\mathrm{ST}, \%)$ reactions, we used the first formula: $(b+c+d)=(100-a)$. Using the second formula: $\mathrm{SI}=\mathrm{ST} / \mathrm{SP}$, we calculated the stimulation index (SI).

Reactive oxygen species (ROS) formation was visualized to assess the result of $\mathrm{NADH}-\mathrm{H}$-oxidase reaction in phagocyte mitochondria. To $100 \mu \mathrm{L}$ of cell suspension $\left(1.0 \times 10^{6} / \mathrm{mL}\right.$ in Live Cell Imaging Solution, Invitrogen, A14291DJ), $5 \mu \mathrm{L}$ of the working solution for the determination of free oxygen species was added following the manufacturer's recommendations for the Cellular Reactive Oxygen Species Detection Assay Kit orange fluorescence (Abcam, ab186028). The solution was mixed by pipetting and incubated for 10 minutes in the room temperature in the dark. Then $1 \mu \mathrm{L}$ of $5 \mathrm{mM}$ DRAQ5 dye solution (Abcam, ab108410) was added for nuclear DNA staining and incubated for $5 \mathrm{mi}$ nutes at room temperature in the dark. The cell suspension was added to the wells of a glass slide (Thermo Scientific TM PTFE, 10632391) and covered with a coverslip (Fisherbrand, 12-542A). Cells were visualized by confocal microscopy using a laser scanning confocal microscope Olympus FV10i-LIV (Olympus, Japan). Fluorescence detection was carried out at $\lambda_{\mathrm{Ex}}=540 \mathrm{~nm}, \lambda_{\mathrm{Em}}=570 \mathrm{~nm}$ for the detection of ROS and $\lambda_{\mathrm{Ex}}=$ $646 \mathrm{~nm}, \lambda_{\mathrm{Em}}=697 \mathrm{~nm}$ for the detection of the DNA-DRAQ5 complex. The sensitivity of the detectors and the intensity of the lasers in all studied samples were the same. Images were taken using x60 NA1.2 objective with water immersion. A number of horizontal optical sections were taken through the entire volume of cells with a step of $1.0 \mu \mathrm{m}$. Images were saved for further processing and analysis in OIF format. Image deconvolution, and measurement of relative fluorescence intensity (rfu / cell) were performed using the CellSense Dimension Desktop software (Olympus).

The presence of ANCA was determined by the method of direct immunofluorescence using donor neutrophils (slides with biochip reaction zones, the surface of which is covered with a substrate) fixed with ethanol, which makes it possible to differentiate the main types of autoantibody fluorescence. The slides were incubated at the first stage of the reaction with the diluted patient's blood serum samples. The specific antibodies of the IgA, IgG and IgM classes present in positive samples bind to the corresponding antigens. At the second stage, the bound antibodies were detected by fluorescent staining, which occurs as a result of incubation of the slides with fluorescein-labeled (FITC) antibodies to the corresponding human immunoglobulins (EUROIMMUN reagent kit, Germany). Fluorescence was assessed using an Olympus BX53 (Olympus, Japan) fluorescent microscope $(\mathrm{x} 400)$. There are two main types of ANCA fluorescence: cytoplasmic and perinuclear. In the cytoplasmic type ANCA
(cANCA), the fluorescence of granules localized in the cytoplasm of the cell between the neutrophil nucleuses lobes. When the perinuclear type (pANCA) is detected, the glow seems to outline the neutrophil nucleus lobes, leaving the cell nucleus unstained.

To detect serum specific antinuclear antibodies (ANA) by indirect immunofluorescence assay, we used MABs labeled with FITC and glasses with biochip reaction zones, the surface of which was coated with the substrate: HEP-2 (human laryngeal cancer epithelial cells) and primate liver sections (EUROIMMUN reagent kit, Germany). The slides were incubated at the first stage of the reaction with samples of diluted blood serum from the patients. The specific antibodies of the IgA, IgG and IgM classes present in positive samples bound to the antigens. At the second stage, the bound antibodies were detected by fluorescence staining, which occurs as a result of incubation of slides with fluorescein-labeled (FITC) antibodies to the corresponding human immunoglobulins. Fluorescent specificity was assessed using an Olympus BX53 microscope (Olympus, Japan), $\times 400$. We determined the presence of certain antibodies by the type of glow in accordance with the International Consensus on ANA Patterns (ICAP) (Tkachenko et al., 2020).

The statistical processing of the obtained results was performed by Statistica 6.1 (StatSoft Inc., USA, 2001). The experiment data were presented as $\mathrm{x} \pm \mathrm{SD}$ (standard deviation). Differences between the values of the control and experimental groups were determined using the Tukey test, where the differences were considered significant at $\mathrm{P}<0.05$.

\section{Results}

Complement proteins are one of the main factors involved in immune responses. In patients with hepatosplenomegaly, there were revealed multidirectional changes in the concentration of complement components in different groups (Table 1). In group I, the content of the $\mathrm{C} 3$ component was increased by $10.1 \%$ compared with the reference values, leading to increase in the chemotaxis of phagocytic cells, as evidenced by an increase in the phagocytic number in group I, and the formation of circulating immune complexes in this group due to the activation of their formation by $\mathrm{C} 3$ complement. In group II with hepatosplenomegaly and viral herpes persistence, we observed the maximum increase in C3 component 1.5 times, which promoted the activation of all stages of oxygen-independent phagocytosis. In group III, this indicator did not significantly differ from the reference values (Table 1).

\section{Table 1}

The content of $\mathrm{C} 3$ and $\mathrm{C} 4$ complement system components in patients with splenomegaly of various etiologies $(x \pm S D)$

\begin{tabular}{lcc}
\hline \multicolumn{1}{c}{ Study groups } & $\begin{array}{c}\text { C3 component, } \\
\mathrm{mg} / \mathrm{dL}\end{array}$ & $\begin{array}{c}\mathrm{C} 4 \text { component, } \\
\mathrm{mg} / \mathrm{dL}\end{array}$ \\
\hline Reference values $(\mathrm{RV})$ & $105.1 \pm 5.7^{\mathrm{a}}$ & $25.3 \pm 1.1^{\mathrm{a}}$ \\
Group I, HBV/HCV $(\mathrm{n}=52)$ & $117.5 \pm 12.6^{\mathrm{a}}$ & $15.7 \pm 2.9^{\mathrm{b}}$ \\
Group II, CMV/EBV $(\mathrm{n}=48)$ & $153.1 \pm 5.9^{\mathrm{b}}$ & $19.9 \pm 3.5^{\mathrm{a}}$ \\
Group III, hereditary enzymopathies $(\mathrm{n}=15)$ & $122.4 \pm 7.1^{\mathrm{ac}}$ & $24.1 \pm 0.9^{\mathrm{a}}$ \\
\hline
\end{tabular}

Notes: differences between the reference values and different groups are indicated by different latin letters $(\mathrm{P}<0.05)$ according to the Tukey test.

The concentration of $\mathrm{C} 4$ component in group I was significantly reduced - 1.6 times, in group II - 1.2 times compared with the reference level, and in group III - remained at the reference interval level (Table 1). Increased activity of the key component of complement system (C3) in group II indicated its overproduction; therefore, hyperfunctional of $\mathrm{C} 3$ convertase occurred during of the membrane-attacking complex (MAC) formation. A decrease in the content of $\mathrm{C} 4$ in the blood serum indicated impairment in clearance of the immune complexes by inhibition of the reception of Fc fragments of antibodies and cleavage of the antigen by complement-dependent lysis, as well as decrease in phagocytosis of soluble immune complexes containing IgM.

Determining the functional state of phagocytic cells at different stages of phagocytosis using acridine orange allowed us to visualize the adhesion of microorganisms, the absorption and digestion capacity of neutrophilic granulocytes. In group I, the number of phagocytes (phagocytic index $\mathrm{PhI}$ ), their adhesive and absorptive (phagocytic number $-\mathrm{PhN}$ ) capacities were maximally high against the background of low rates of completion 
of phagocytosis $(\mathrm{CPh})$, which is shown in Figure la and $1 \mathrm{~b}$ - neutrophils are visible, glowing with green light, filled with a large number of captured microorganisms. The green colour of the captured yeast $S$. cerevisiae labeled with acridine orange was characteristic of the native nucleic acids. Within 45 minutes, under the action of lysosomal enzymes of neutrophils, the microorganisms' DNA was denatured and the glow colour gradually changed to orange, then to red. The transition of double-stranded DNA to single-stranded DNA was characterized by intensive digestion of the antigen by lysosomal enzymes of neutrophils, and undigested antigens retained the green luminescence of the native DNA. The low number of active phagocytes $(\mathrm{APh})$ in this group indicates the failure of the digestive function of neutrophils (Fig. 1b). In group II, the parameters characterizing the first and second stages of neutrophil phagocytosis were at the level of reference values. The intensity of the red (orange) fluorescence of denatured DNA characterized its high-molecular fragmentation at the stage of activity of lysosomal neutrophil enzymes (Fig. 1c, d). The number of active neutrophils did not differ from the reference values.

In III group, there was a low relative content of neutrophils participating in phagocytosis in the peripheral blood $-42.3 \pm 7.6 \%$, and their absorption capacity was also low - the phagocytic number was $2.1 \pm 0.2$.
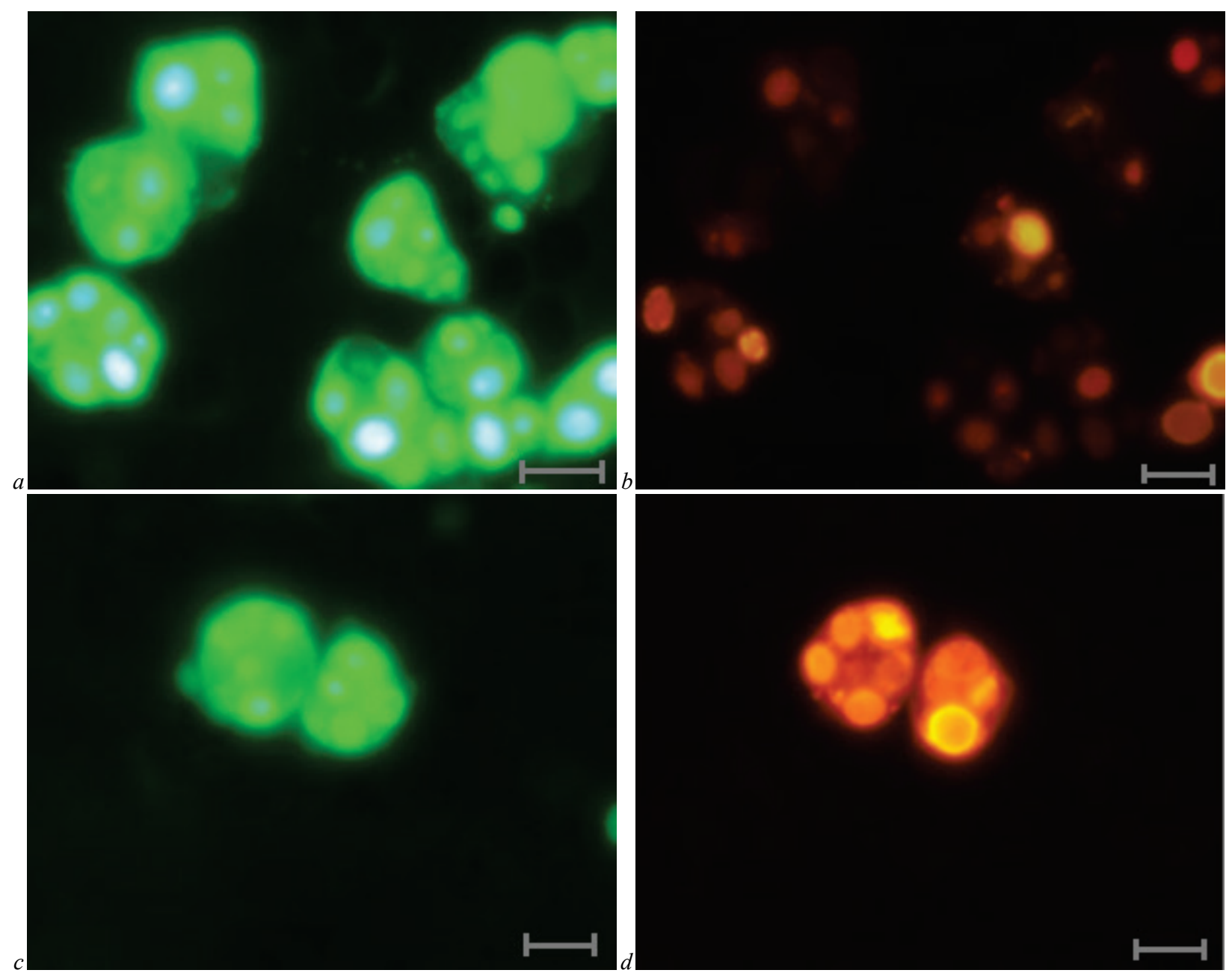

Fig. 1. DNA denaturation of $S$. cerevisiae at different stages of granulocytic neutrophils phagocytosis (fluorescence microscopy with acridine orangeAO): $a, c$-start of incubation - native DNA (green colour), AO staining $\left(\lambda_{\max }=530 \mathrm{~nm}\right.$ ); $b$ (group I) - the probe after 90 minutes from the start of incubation,

lack of microorganisms' complete digestion, AO staining $\left(\lambda_{\max }=640 \mathrm{~nm}\right.$ ); $d$ (group II) - the probe in 90 minutes after the start of incubation, colour change (orange colour indicates DNA denaturation - intensive digestion of absorbed microorganisms and complete denaturation of the microorganisms DNA during their apoptosis in phagocytes; bar $10 \mu \mathrm{m}$

Absence of colour change of microorganisms inside phagocytes from green to red - the process of phagocytosis was not completed. $\mathrm{PhI}-$ phagocytic index - the number of phagocytic neutrophils (\%) (RV 60-80\%); $\mathrm{APh}$ - active phagocytes - digesting a minimum of antigens (RV 80$100 \%) ; \mathrm{PhC}$ - the number of microorganisms absorbed by 1 neutrophil (RV 2.0-4.0 units); $\mathrm{CPh}$ - completion of phagocytosis - complete endocytosis of neutrophils digesting microorganisms (RV 70-90\%). Thus, a low digestive activity of neutrophils was detected in patients of groups I and III - in the test with $\mathrm{AO}$, the non-digested antigens retained the native form of their DNA and, accordingly, a green glow of constant intensity. In patients with hepatosplenomegaly and CMV/EBV viruses (group II), the digestive ability was at the level of reference values, as indicated by the bright orange fluorescence of microorganisms' denatured DNA. Oxygendependent phagocytosis was assessed in the NBT-test and by the intensity of the reactive oxygen species (ROS) formation. With prolonged action of the antigenic load, including a viral nature, enzymes induced by singlet oxygen generated are activated in neutrophils. The reactions of absorption and digestion in neutrophils are accompanied by the ROS formation, mainly in the membranes of cells and in the membranes of phagosomesdue to the NADP-H-oxidase activation. As an effect of the electrons transfer to oxygen by this enzyme, superoxide anion $\left(\mathrm{O}^{2}\right)$, hydrogen peroxide $\left(\mathrm{H}_{2} \mathrm{O}_{2}\right)$ and a number of other ROS are formed. This has a strong microbicidal effect, and a direct destructive effect on the cellular structures. In all the groups, an increase in the spontaneous oxidative reaction was revealed in oxygen-dependent phagocytosis, which indicates the presence of prolonged inflammatory stress against the background of the antigenic load (Fig. 2a, b). The most pronounced increase in spontaneous reaction $56.5 \pm$ $2.3 \%$ was noted in group III of patients with hereditary enzymopathies (Table 2, Fig. 2c). To assess the functional oxidative reserve of neutrophils, an NBT-test induced by opsonized zymosan was performed (ST). A significant increase in formazan-positive cells was found in groups I and III (Table 2, Fig. 2d, f). The level of zymosanstimulated neutrophils in group II did not differ from the reference values, but was lower than in groups I and III (Table 2, Fig. 2e). 
Due to a significant increase in spontaneous oxidation (SP) of diformosan grains, the stimulation index (SI), which indicated the integral bactericidal activity of phagocytes, was significantly reduced in all the groups, but it was the lowest in groups I and II, suggesting insufficient activity of the NADP-H-oxidase system and depletion of the oxidative reserve of neutrophils (Table 2). To determine the level of ROS formation on mitochondrial membranes as a result of processing of antigens by neutrophils, oxygen-dependent phagocytosis was assessed ex vivo using confocal microscopy. In group I with hepatosplenomegaly and hepatitis HBV / HBC viruses, the spontaneous level of ROS was lower than in group II of patients with hepatosplenomegaly and herpesvirus persistence.
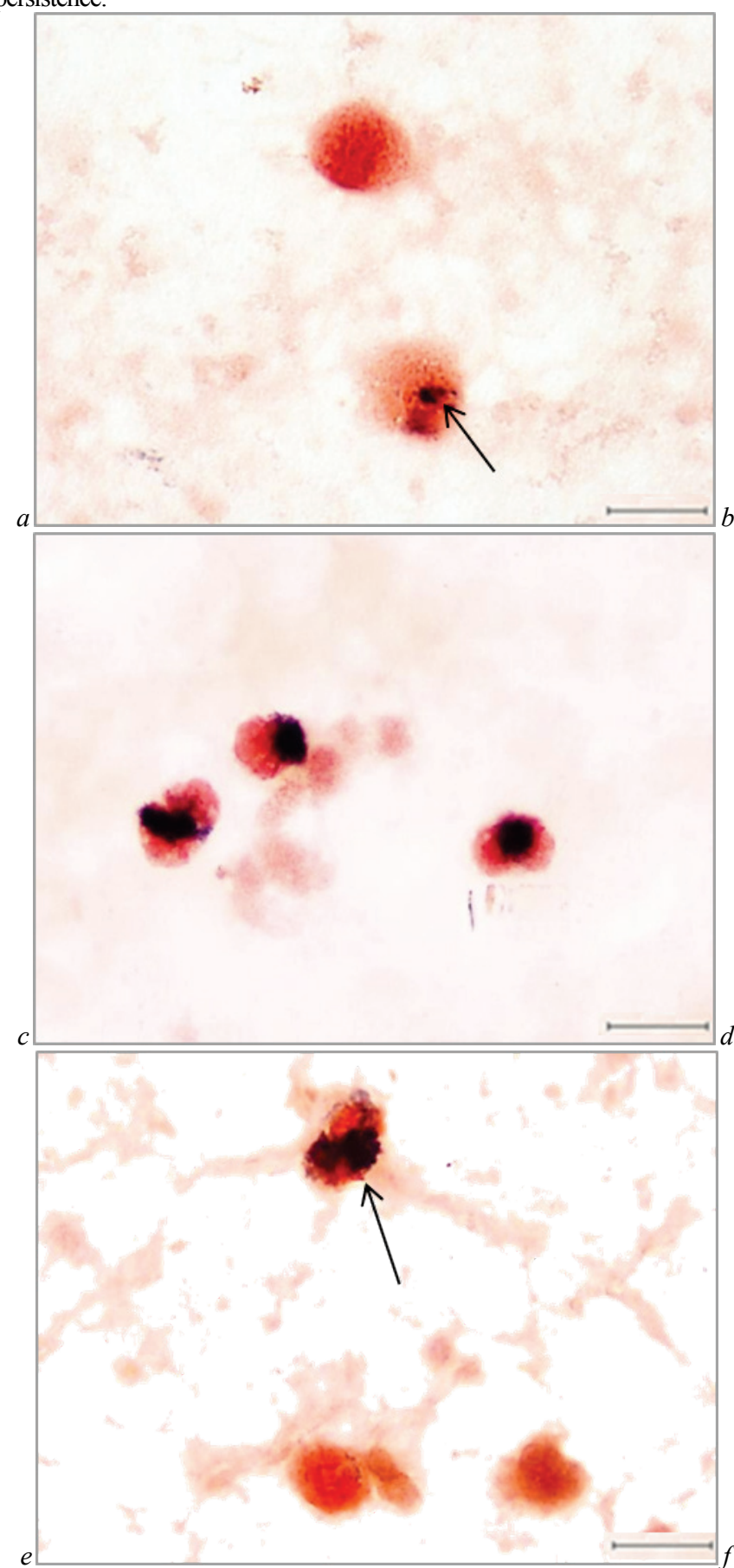

Fig. 2. Neutrophilic granulocytes in intracellular redox reactions (NBT test): $a, b, c$-neutrophils that absorbed the NBT dye and reduced it to diformosan (spontaneous reaction, SP); $d, e, f$-neutrophil induced by zymosan (white granules of diformosan) (stimulated reaction, $\mathrm{ST}$ ); the arrow indicates the appearance of oxidized diformazan granules under the action of ROS and enzymes, in particular MPO; light microscopy; bar $10 \mu \mathrm{m}$

Differences in the ROS content in group I at high spontaneous $(\mathrm{ST}=6386.0 \mathrm{rfu})$ and stimulated $(\mathrm{ST}=7694.8 \mathrm{rfu})$ oxidation did not significantly differ from each other (Fig. 3a, b). In group II of patients,
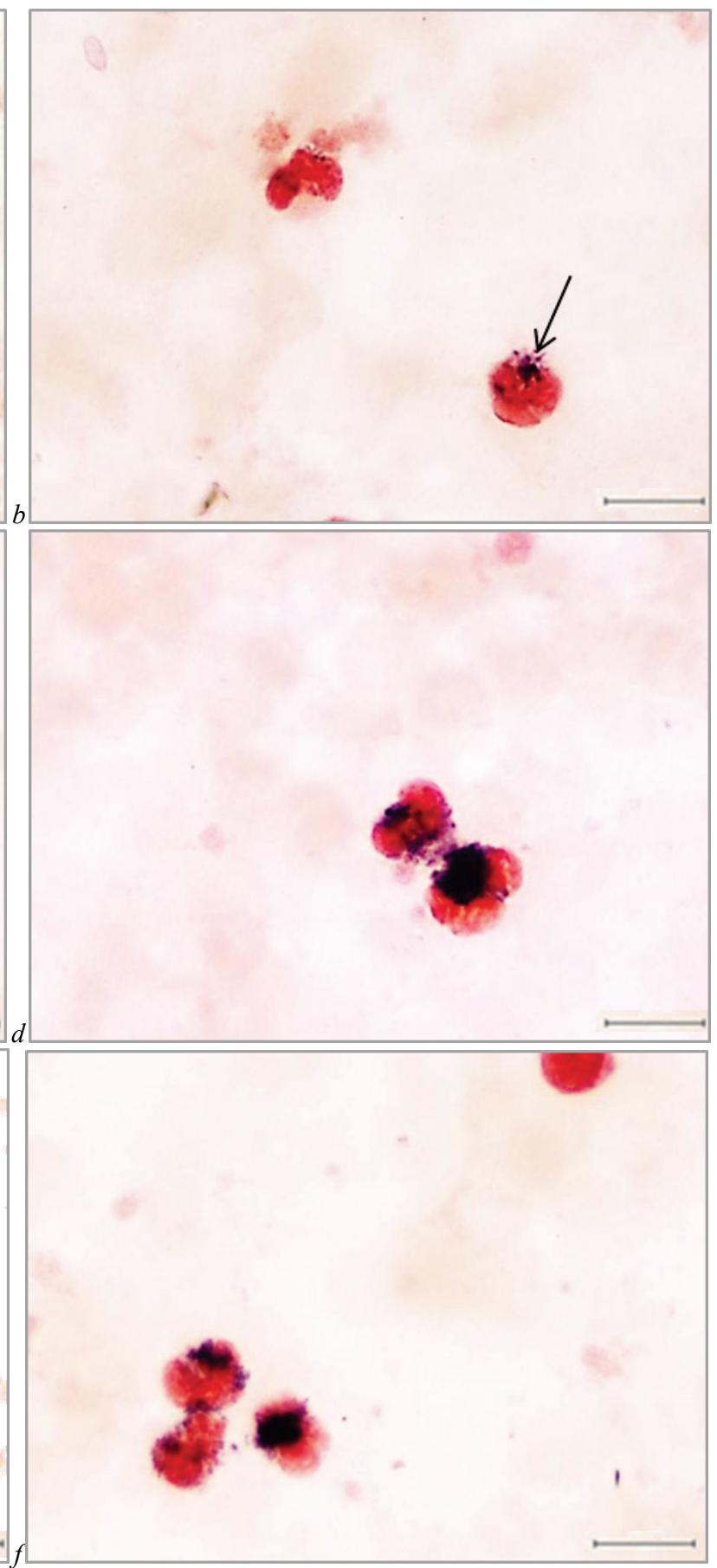

Table 2

The state of oxygen-dependent metabolism of neutrophils in patients with liver cirrhosis and splenomegaly of various etiologies $(x \pm S D)$

\begin{tabular}{lccc}
\hline \multicolumn{1}{c}{ Study groups } & SP, $\%$ & ST, $\%$ & SI, units \\
\hline Reference values $(\mathrm{RV})$ & $10.1 \pm 0.7^{\mathrm{a}}$ & $65.2 \pm 2.9^{\mathrm{a}}$ & $7.12 \pm 0.51^{\mathrm{a}}$ \\
Group I, HBV/HCV $(\mathrm{n}=52)$ & $53.3 \pm 5.6^{\mathrm{b}}$ & $81.8 \pm 3.8^{\mathrm{b}}$ & $1.43 \pm 0.06^{\mathrm{b}}$ \\
Group II, CMV/EBV $(\mathrm{n}=48)$ & $46.5 \pm 2.9^{\mathrm{b}}$ & $67.5 \pm 4.1^{\mathrm{ab}}$ & $1.51 \pm 0.08^{\mathrm{b}}$ \\
Group III, hereditary & $56.5 \pm 1.8^{\mathrm{b}}$ & $79.5 \pm 2.8^{\mathrm{b}}$ & $1.43 \pm 0.04^{\mathrm{b}}$ \\
enzymopathies $(\mathrm{n}=15)$ & & &
\end{tabular}

Notes: differences between the reference values and different groups are indicated by Notes: differences between the reference values and differt
different latin letters $(\mathrm{P}<0.05)$ according to the Tukey test.

the difference between the ROS content during spontaneous oxidation $(\mathrm{SP}=8221.3 \mathrm{rfu})$ and after antigenic stimulation with zymosan $(\mathrm{ST}=$ $15928.3 \mathrm{rfu}$ ) was high and accounted for $45.5 \%$, suggesting a notable 
oxidative process in neutrophil mitochondria (Fig. 3c, d). This confirms the similarity of the results obtained for determining the functioning of oxygen-dependent phagocytosis by the two methods.

With a decrease in the effectiveness of the body antioxidant systems, ROS can have a damaging effect on cells and cause various pathological conditions. Released into the surrounding space from neutrophilic granules of neutral proteases are able to activate the kallikrein-
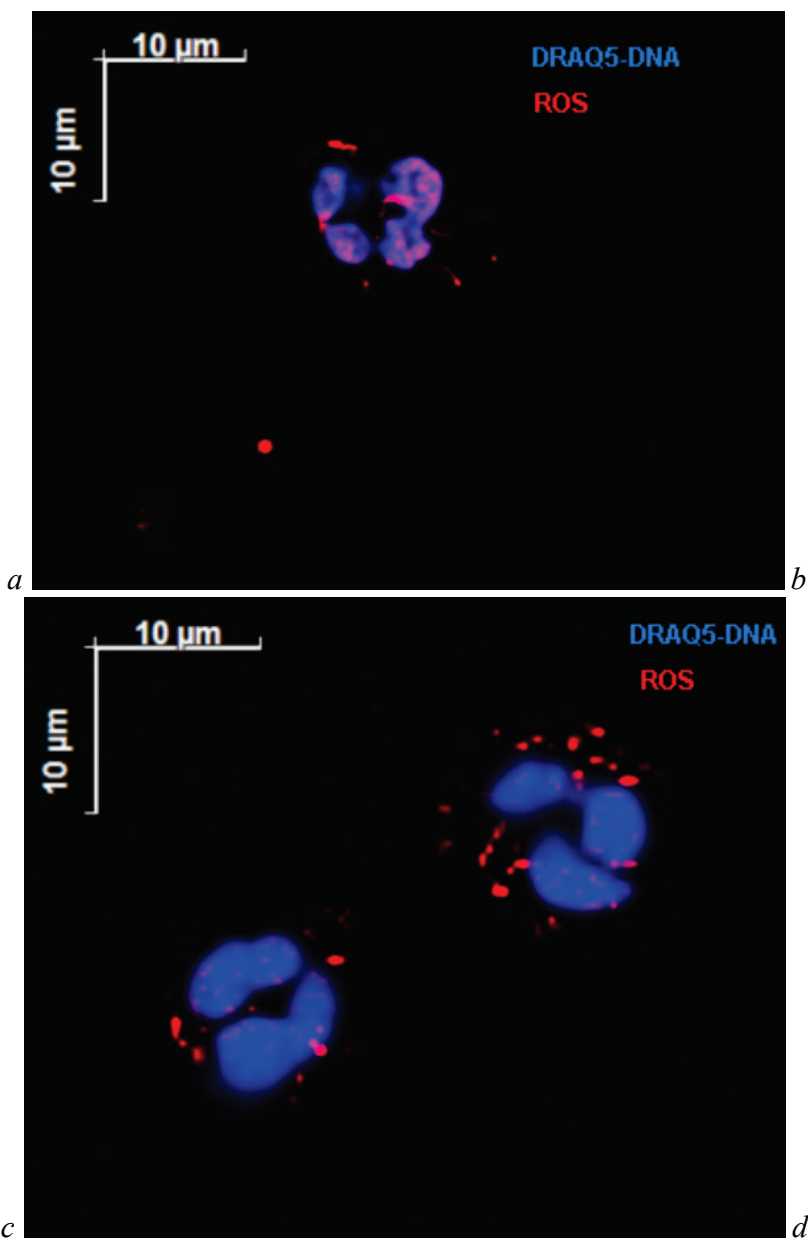

kinin system and have a direct damaging effect on the structural components of the surrounding tissues, which in the future can lead to the formation of autoantibodies to them. Analysis of the results obtained from patients with various etiologies hepatosplenomegaly for the antineutrophil antibodies presence revealed that in group I (HBV/HCV) these antibodies were detected in $62.5 \%$ cases; $50.5 \%$ - had pANCA (Fig. 4a), 12.5\% had cANCA (Fig. 4b).
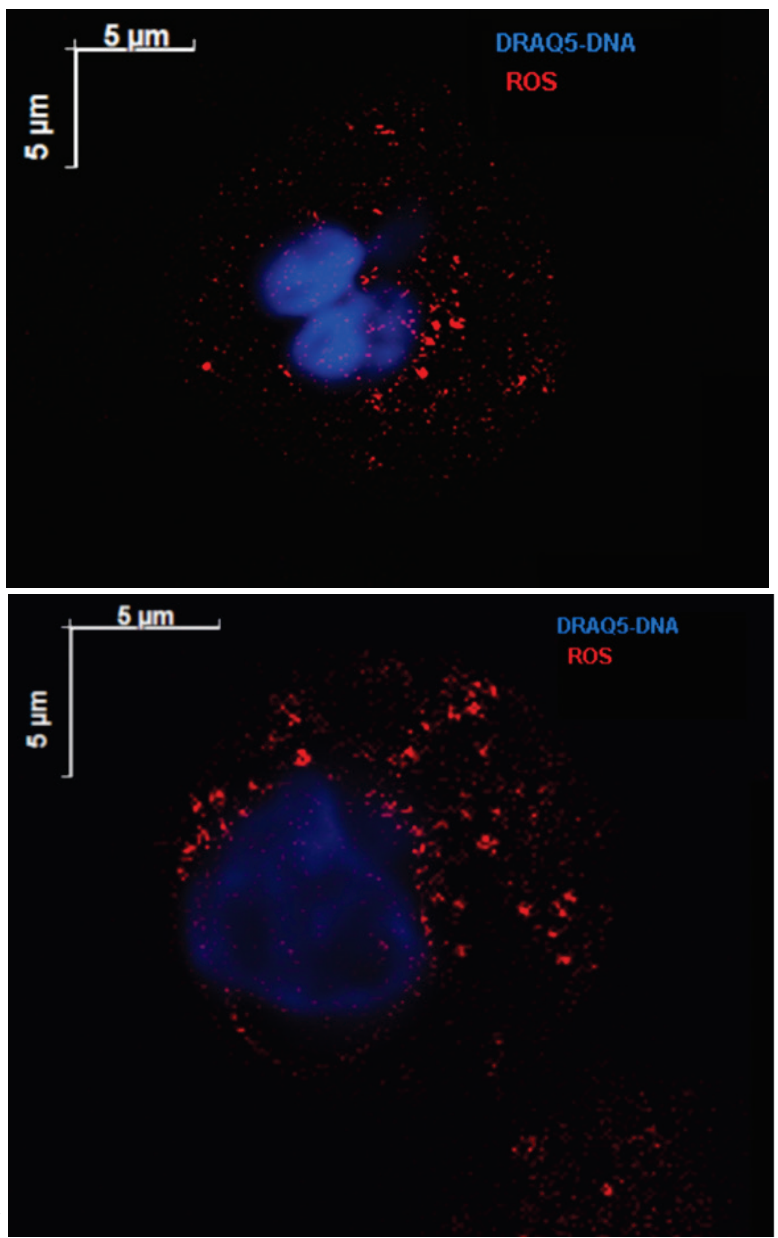

Fig. 3. ROS localization on the membranes of neutrophils cell structures in patients with hepatosplenomegaly: $a$-moderate red glow of ROS with spontaneous unstimulated phagocytosis (group I-HBV/HBC); $b$ - slight increase in the ROS fluorescence upon stimulation of phagocytosis with zymosan (group I-HBV/HBC); $c$ - more intense ROS fluorescence on phagocyte membranes during spontaneous unstimulated phagocytosis (group II -

$\mathrm{CMV} / \mathrm{EBV}$ ) compared to the group I; $d$ - significant activation of the ROS formation after stimulation of NADP-H-oxidase reactions, an increase in the concentration of ROS on the membranes of neutrophils of cytoplasmic structures (group II - CMV/EBV); laser scanning confocal microscopy
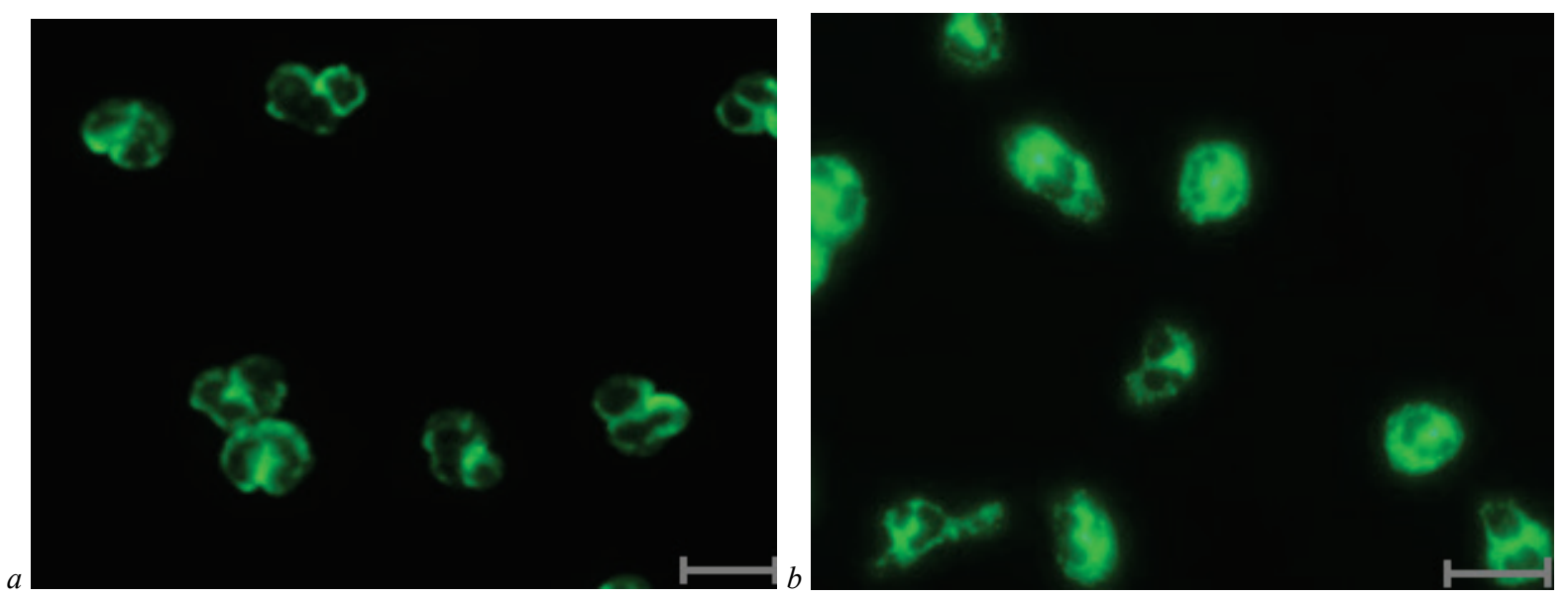

Fig. 4. Perinuclear ANCA fluorescence pANCA $(a)$ and cytoplasmic ANCA fluorescence cANCA $(b)$ : FITC staining of standard granulocyte cytoplasm antigenic substrates after interaction with serum antibodies, bar $10 \mu \mathrm{m}$ 
An ANCA-positive patient accounted for $85.7 \%$ in group II (CMV/EBV). And patients with the pANCA prevailed (71.4\%), with cANCA $-14.3 \%$. In group III of patients with hereditary enzymopathies, ANCA was detected in $67.3 \%$ of the examined, while pANCA and cANCA were found with the same frequency in $33.5 \%$ of patients.

All patients with liver cirrhosis and various etiologies splenomegaly against the background of long-term viral persistence: the presence of $\mathrm{HBV}, \mathrm{HCV}$ viruses (group I) and herpes viruses CMV, EBV (group II) revealed a wide range and high frequency of antinuclear antibodies (ANA). In groups I and II, 8 and 11 specificities of ANA were found respectively. Moreover, both groups were characteristic of 5 specificities. Deviations from the normal functioning of the centromere lead to problems in the mutual arrangement of chromosomes in the dividing nucleus, and as a result - to disturbances in the process of chromosome segregation (Table 3).

The presence of autoantibodies to mitochondria, which was also detected in these patients, can lead to mitochondria dysfunction and ATP deficiency, which complicates the aminoacyladenylate formation. The presence of autoantibodies to the pyruvate dehydrogenase complex can lead to disruptions in the oxidative decarboxylation of pyruvate and disruption of the high-energy acetyl-CoA formation.
Also, in both groups, autoantibodies to F-actin were detected, which can lead to dysregulation of the actin cytoskeleton, induction of autoimmune reactions and malignancy (Table 3 ). In addition to the above-mentioned autoantibodies, antibodies to 3 more antigens, characteristic only for this group, were found in group I. These were autoantibodies to Cajal bodies that contain high concentrations of small nuclear ribonucleoproteins and other factors of RNA processing, and may indicate the participation of these nuclear formations in the assembly and post-transcriptional modification of the splicing nuclear apparatus. The presence of autoantibodies to tropomyosin can lead to functional disorders of the thin filament. Also, in group II, 2 specificities of ANA were revealed, which are also characteristic of group III: to ribonucleoproteins U1-RNP and to proteins SP-100, PML associated with PML bodies (Table 4). Ribonucleoproteins (U1$\mathrm{RNP}$ ) are involved in the processes of alternative pre-mRNA splicing, being part of the spliceosome. The presence of antibodies to this antigen can disrupt these processes and lead in the future to a change in the synthesis of extracellular matrix proteins; also impaired splicing does not allow cells to "adjust" the structure of gene products to their respective various special needs in pathological conditions. In group III (hereditary enzymopathies), ANA of only two specificities was observed, which were also characteristic of group II (Table 4).

Table 3

Specificity of antinuclear antibodies (ANA) in patients with liver cirrhosis and hepatosplenomegaly (group I and II)

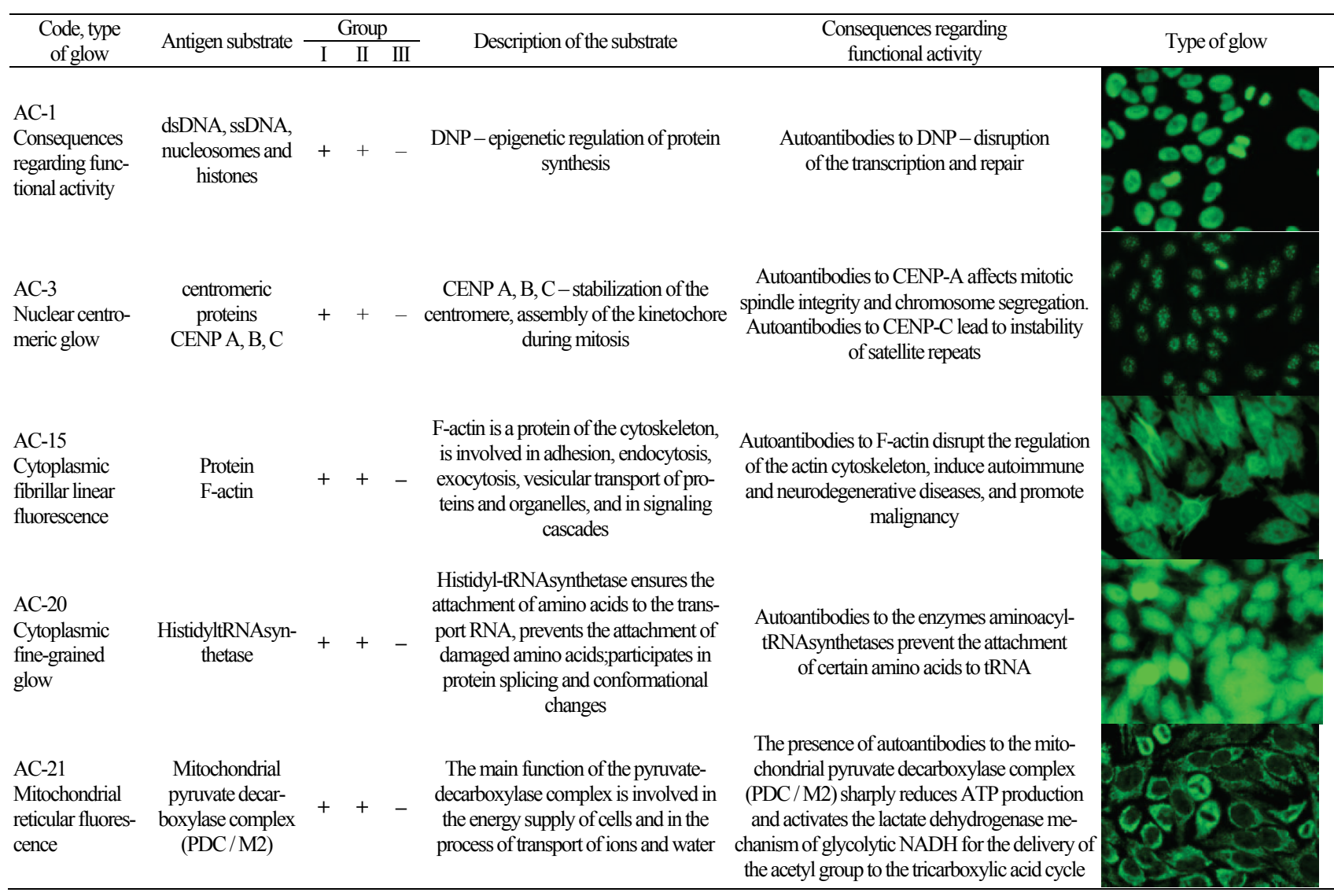

Note: the Table shows the types of the antinuclear factor (ANF) fluorescence by codes (AC - anti-cell pattern) in accordance with the International Consensus on ANA Patterns (ICAP).

\section{Discussion}

In the development of the autoimmune component in the form of formation of the autoimmune antibodies and aggressive clones of T lymphocytes to their own autoantigens, along with the known genetic predictors (polymorphism of the HLA-DR genes and dysfunction of the AIREcomplex, which ensures the recognition of its own antigens), the destructive effect on the cells of the body involves many factors of immunological protection. A powerful tool both for protecting the body against pathogens and removing apoptotic cells is the complement system, which is one of the main links of the innate immune system, and its activation serves to link the innate and adaptive immune responses. The significant decrease in the C4 complement component was observed in group I; in our opinion, this was due to the consumption of antigen-antibody-complement immune complexes. The activators of complement components and various effector cells may be IgG antibodies against infectious antigens and other endogenous antigens, the interaction of which ensures the formation of immune complexes. Such complexes of small sizes can deposit in the tissues and lead to complement deficiency due to its consumption (C4 component). Inadequate clearance of immune complexes and extrahepatic replication of the virus in target tissues (in mononuclear blood cells, lymph nodes, spleen, bone marrow) determines the clinical picture 
of systemic manifestations of viral hepatitis, including hepatosplenomegaly (Robinson et al., 2016). The emerging autoimmune reactions play a leading role in the development of extrahepatic manifestations (De Oliveira et al., 2018). In group II (hepatosplenomegaly with herpes infection), activation of $\mathrm{C} 3$ complement component was seen ( $43.4 \%$ higher compared to the reference values). The $\mathrm{C} 3 \mathrm{a}$ and $\mathrm{C} 3 \mathrm{~b}$ proteins of the complement system promote the binding of phagocytes to antigens, and their activation can lead to increase in energy-dependent phagocytosis and stimulate the formation of a large number of leutkotrienes and prostaglandins as a result of degradation of the outer mitochondrial membrane. These processes activate the formation of autoantibodies to this organoid, since the components of destroyed mitochondria are structurally similar to the components of bacterial cells (mtDNA and formyl peptides) and the immune system reacts to them as to an infection. Activation of $\mathrm{C} 3 \mathrm{com}-$ ponent leads to the induction of neutrophil migration, direct complementdependent lysis of target cells and increased inflammatory responses (Brilland et al., 2020). In addition, cytomegalovirus (CMV) is able to enhance the expression of host complement inhibitors, as well as interfere with the classic pathway of complement activation by avoiding the binding of complement with the antibody-antigen complex, either by removing these complexes from the cell surface of the infected cell, or by expressing Fc receptors (Spiller et al., 1996).

Table 4

Specificity of antinuclear antibodies in patients of groups II and III with liver cirrhosis on the background of hepatosplenomegaly

\begin{tabular}{|c|c|c|c|c|c|c|c|}
\hline \multirow{2}{*}{$\begin{array}{l}\text { Code, type } \\
\text { of glow }\end{array}$} & \multirow{2}{*}{$\begin{array}{l}\text { Antigen } \\
\text { substrate }\end{array}$} & \multicolumn{3}{|c|}{ Group } & \multirow{2}{*}{$\begin{array}{c}\text { Description } \\
\text { of the substrate }\end{array}$} & \multirow{2}{*}{$\begin{array}{c}\text { Consequences regarding } \\
\text { functional activity }\end{array}$} & \multirow{2}{*}{ Type of glow } \\
\hline & & I & II & III & & & \\
\hline $\begin{array}{l}\text { AC-5 } \\
\text { Nuclear } \\
\text { coarse-grained } \\
\text { glow }\end{array}$ & $\begin{array}{l}\text { Ribonucleoproteins } \\
\text { U1-RNP }\end{array}$ & - & + & + & $\begin{array}{c}\text { The U1- } \mathrm{SnRNP} \text { complex is one } \\
\text { of the main components of the } \\
\text { spliceosome }\end{array}$ & $\begin{array}{c}\text { Autoantibodies to U1-RNP leads to high } \\
\text { inflammatory activity against the back- } \\
\text { ground of a high titer of CRP and ESR, } \\
\text { resulting in tissue damage }\end{array}$ & \\
\hline $\begin{array}{l}\text { AC-6 } \\
\text { Many nuclear } \\
\text { points }\end{array}$ & Proteins SP-100, PML & - & + & + & $\begin{array}{l}\text { Regulation of genome stability, } \\
\text { transcription, DNA repair, cellular } \\
\text { response to stress and viral infec- } \\
\text { tion }\end{array}$ & $\begin{array}{l}\text { Autoantibodies to PML- bodies leads to a } \\
\text { decrease in the ability of interferons to } \\
\text { protect against viral infections }\end{array}$ & \\
\hline
\end{tabular}

Note: the Table shows the types of the antinuclear factor (ANF) fluorescence by codes (AC - anti-cell pattern) in accordance with the International Consensus on ANA Patterns (ICAP).

For the realization of the innate immunity functions, humoral factors such as cytokines are necessary. In group I, significant decrease in the IL$1 \beta$ concentration, the primary inducer of the signaling pathway of proinflammatory cytokines, was found, and IL-18, also belonging to the IL-1 family, was threefold increased; whereas in group II, both cytokines increased significantly. The content of TNF- $\alpha$ was high in groups I and II, and below the reference values in group III (hereditary enzymopathies). The activation of the pro-inflammatory cytokines' synthesis was accompanied by an increase in IL-6 in all groups, including group III (Klimova et al., 2019). Infectious agents cause the activation of phagocytosis at the early stages of the inflammatory response, which is accompanied by increase in the synthesis of IL-1 $1 \beta, \mathrm{TNF}-\alpha$ and IL-18 in response to the presence of antigen and chronic tissue damage (Klimova et al., 2019). The main function of these cytokines is to maintain tissue homeostasis. A high titer of IL- $1 \beta$ and TNF- $\alpha$ stimulates the development of a local inflammatory response, aimed at eliminating antigens. Induction of IL-1 $\beta$ synthesis activates bone marrow hematopoiesis on the one hand, and initiates catabolic processes in tissues on the other hand, proteolysis in particular. It is known that an increase in the synthesis of cytokines of the IL-1 family has an important role in the manifestation of autoimmune diseases.

Complement system components and cytokines activate oxygenindependent and oxygen-dependent phagocytosis. In oxygen-dependent phagocytosis, ROS generation destroys infectious antigens, leads to changes in the electron transport chains of mitochondria or microsomes with decrease in the ADP content. In the foci of inflammation, myeloperoxidase (MPO) of phagocytes can also be released into the intercellular spaces and cause damage to their own tissues, and an increase in its level can serve as a marker of the inflammatory reactions intensity (Phaniendra et al., 2015). The over-formation and storage of ROS in group II (30.5\% higher than the reference values) caused disorders of the neutrophils' cell membranes. This led to the development of autoantibodies to the cellular components of neutrophils; in oxygen-dependent phagocytosis, in the neutrophils membranes and phagolysosomes, NADP-H oxidase activation occurred. This enzyme transfers electrons to oxygen with the formation of superoxide anion, from which hydrogen peroxide and a number of other ROS, which have a strong microbicidal effect, are formed.

A sufficiently high level of enzyme induction by zymosan characterized normal immunoreactivity, and increase in spontaneous oxidative ac- tivity indicated depletion of the oxidative reserve of neutrophils. Mitochondrial membranes of phagocytes contain an enzymatic complex (NADP-H oxidase) that oxidizes NADP-H to NADP+ by reducing oxygen to a superoxide radical to ensure endocytosis of antigenic substrates (Lam et al., 2010). Lysosomal enzymes in the phagosome destroy microorganisms with the participation of ROS - hydrogen peroxide anion $\left(\mathrm{HO}^{2-}\right)$ and with the formation of hydrogen peroxides $\left(\mathrm{H}_{2} \mathrm{O}_{2}\right)$, hypochlorous acid ( $\mathrm{HCl}$ ), myeloperoxidase (MPO) contained in azurophilic granules of neutrophils. In the membranes of phagocytes, the NADP-Hoxidase complex provides an "oxidative burst" - a rapid excessive formation of the superoxide radical $\left(\mathrm{O}^{2}\right)$ ROS during stimulation of the body's nonspecific defense to destroy infectious antigens. The phagocytic cell releases ROS into the environment, as well as a number of enzymes, including MPO, which catalyzes the formation of hypochlorite $\left(\mathrm{ClO}^{-}\right)$, highly toxic for the destruction of microorganisms, from the chloride and hydrogen peroxide (Bedard \& Krause, 2007).

Increased generation of ROS can exceed the antioxidant capacity of mitochondria, thus damaging cells or triggering apoptosis. High levels of ROS induce free radical oxidation of lipids, proteins, etc., which causes oxidative damage, leading to a change in tissue antigenicity, thus leading to the development of autoimmune reactions. In addition to providing these functions, ROS regulate the processes of proliferation, aggregation of chemotaxis, and intercellular signal transmission. At the stage of development of autophagosome, oxidative stress can cause changes in autophagy processes, number of mitochondria, and the area of the endoplasmic reticulum. Insufficient ROS formation can obstruct the elimination processes of aging or mutant cells of the immune system. Autophagy is also an antiviral defense mechanism against cellular debris and altered cellular organelles. Suppression of autophagy with a decrease in ROS leads to the accumulation of damaged mitochondria and aggregates in the smooth endoplasmic reticulum, which causes damage to the DNP complex, genomic instability, and the formation of autoantibodies to cell nuclei.

High concentrations of ROS can damage cell components such as proteins, lipids, and nucleic acids. The activation of oxidative stress and peroxidation leads to mitochondrial damage, which is accompanied by decrease in glutathione levels. As a result of these processes, there also occurs decrease in the synthesis of the enzyme S-adenosylmethionine synthetase and change in the methionine concentration. In $75.5 \%$ patients of group I, content of methionine increased and content of cysteine decrea- 
sed. In $45.5 \%$ of patients of group II, decrease took place in methionine level, and in $81.4 \%$ - in cysteine (Klimova et al., 2019). Disruption of the methionine metabolic pathways led to the accumulation of homocysteine, which causes increased initiation of apoptosis. Excessive severity of the described reactions may contribute to secondary tissue alteration by products of activated neutrophils degranulation.

Reactive oxygen species are involved in inflammatory processes and can cause autoimmune diseases with the formation of pathological antibodies against DNA. Exposure to ROS increases the antigenicity of DNA and promotes the formation of autoantibodies. Cooke et al. (2003) presented convincing data on the immunogenicity of ROS-DNA in experimental animals (rabbits). DNA was modified with three systems for generating hydroxyl radicals and UV radiation, and then its antigenicity was studied. Different antigenicity profiles of DNA immunogenicity occur depending on the method of ROS production, and ROS-DNA can be a factor in the formation of an antigen-driven immune complex (Cooke et al., 2003). A highly reactive hydroxyl radical can interact directly with chromatin, and lead to the formation of a wide range of products, including DNA-protein crosslinks and DNA strand breaks. Such DNA modifications become immunogenic, and the induced antibodies show antigenbinding characteristics, for example, systemic lupus erythematosus, the prototype of many autoimmune diseases, is characterized by the presence of autoantibodies against multiple nuclear antigens. According to Ahsan et al. (2003), oxidative damage to DNA can lead to various degenerative and autoimmune diseases.

The lack of oxygen-dependent phagocytosis in the NBT-test may be associated with inhibition of the MPO synthesis, or due to a high concentration of ANCA to this enzyme. Particularly important in the pathogenesis of cirrhosis against the background of splenomegaly are antinuclear antibodies (ANA), which make up a special group of autoantibodies, and under certain conditions begin to synthesize to protein molecules that are a structural part of the main components of the cell nucleus and always exhibit pathogenic properties. Natural autoantibodies make up a significant part of the total circulating immunoglobulins and provide homeostatic functions in the immune system, reflecting the characteristics of the individual antigenic composition at the organismic level. Change in the antigenic composition of cells increases the production and secretion of certain autoantibodies of a new spectrum, which can be included in the compensatory mechanisms of altered functions. Primary disorders in the structure of the repertoire and the number of autoantibodies mainly depend on quantitative abnormalities induced by various factors, including infectious ones, which are the direct cause of the development of various diseases.

In groups I and II, a wide spectrum and high frequency of occurrence of ANA were revealed -8 and 11 specificities, respectively. Moreover, 5 specificities for the same antigens were characteristic of both groups: double-stranded DNA, histones; chromosome centromeres; to histidyl tRNA synthetase; to the pyruvate-dehydrogenase complex of mitochondria (PDC/M2); to F-actin. The general specificity of antinuclear antibodies was also revealed in patients of groups II and IIII: to ribonucleoproteins U1-RNP and proteins SP-100, PML. Today PML bodies are considered as a signaling system of innate immunity that provides protection against viral infections. In viral infections, viral genomes and proteins often accumulate inside PML (promyelocytic leukemia) bodies. In many DNA viruses the genomes of which replicate in the nucleus, such as human cytomegalovirus (CMV) or herpes simplex virus type 1 (HVS-1), the genomes bind to PML bodies as soon as they enter the nucleus. In PML bodies, the genomes undergo epigenetic silencing, which suppresses the development of infection. PML body proteins such as, DAXX (deathassociated protein 6), SP100, and ATRX are involved in suppressing viral infections (Lallemand-Breitenbach \& de The, 2018). The deficiency of PML bodies, as a result of the presence of autoantibodies to them, decreases the ability of interferons to protect against viral infections. PML bodies are associated with other cytokines. For example, in cells lacking PML, there is a decreased expression of the pro-inflammatory cytokines IL-1 $\beta$ and IL-6 (Scherer \& Stamminger, 2016). Moreover, in group II, antibodies to the fibers of the mitotic spindle were detected; to laminas fibrillar proteins that provide structural function and regulation of transcription in the cell nucleus. Thus, for all types of autoantibodies we identi- fied, the immunogenic targets were the components that were directly involved in protein biosynthesis: from transcription, alternative splicing, and to translation. In autoimmune diseases, antinuclear and antineutrophil antibodies trigger an immune response, with the formation of cytotoxic factors leading to cell lysis and tissue destruction. High frequency of occurrence and broad range of specificities of antinuclear antibodies were found in groups of patients with persistent viral infection.

Natural antibodies make up a certain part of circulating immunoglobulins and provide the main homeostatic functions of the immune system recognition of foreign antigens, because active biological processes in various tissues lead to the processes of cellular aging and renewal. At the organismic level, natural autoantibodies reflect the characteristics of the antigenic composition of the organism. Also, autoantigens can be formed as a result of external exposure to exogenous biological and physical factors (infections, toxins, radiation). Change in the natural composition of cells induces the production and secretion of the identified spectrum of autoantibodies, and the compensatory mechanisms of altered functions. Modified nucleotides in DNA obtained from immune complexes of patients with autoimmune pathology indicate that ROS may be involved in their pathogenesis. On the other hand, during autoimmune diseases, there are increased apoptosis and decline in the apoptotic cells clearance, which may be a factor contributing to systemic autoimmunity. Box et al. (2001) revealed damage to the double helix of DNA after exposure to ROS, followed by the formation of free radicals. The authors note that DNA damage involves the involvement of guanine, which has potential biological significance. Cadet et al. showed that DNA oxidation occurs with the participation of $\mathrm{OH}$-radicals and singlet oxygen in the form of double DNA damage (including purine and pyrimidine bases), which increases its immunogenicity (Cadet et al., 2002). The reason for the formation of autoantibodies can be the accumulation of antigens, which are induced not only by ROS, but also by nitric oxide formed in oxygen-dependent phagocytosis (Dixit \& Ali, 2001). In case of disruptions of any links of immunogenetic control, intensive formation of autoantibodies occurs, which can be synthesized to the protein components of the DNP complex and always exhibit the highest pathogenic properties, since they disrupt biosynthetic processes: transcription, replication, and repair. Violation of the chromosome segregation due to deviations from the normal functioning of the centromere lead to problems in the mutual arrangement of chromosomes in the dividing nucleus, and as a result - to disturbance.

Thus, the main mechanisms of damaging the organ in patients of group I with viral hepatitis include direct cytotoxic effect, immune-mediated, by direct action of cytotoxic $\mathrm{T}$ lymphocytes towards the target cell with intracellular viral antigens or cytokine-mediated lysis of hepatocytes, and virus-induced autoimmune reactions. The combination of exogenous and endogenous factors in group II induced over-activation of immunoreactivity in response to the infectious antigens and to the absence of immunogenetic control of the altered autoantigens, causing the synthesis of the autoantibodies, which may destroy the cells and tissues.

\section{Conclusion}

The analysis of the immunological data we obtained revealed significant diagnostic markers. We developed the analysis algorithm and determined differences in significant markers between the studied groups of patients with liver cirrhosis and autoimmune hepatitis complicated by heptosplenomegaly.

In group I (hepatitis $\mathrm{B}$ and $\mathrm{C}$ viruses), decrease in $\mathrm{C} 4$ component was revealed, which triggered antigen-antibody complexes (immune complexes), apoptotic bodies and necrotic cells; significant increase in the phagocytic index and the phagocytic number of phagocytes was also shown, against the background of a reduced number of active phagocytes and the index of digestion. Significant decrease in the concentration of IL-1 $\beta$ was found, and IL-18, which also belongs to the IL-1 family, was threefold increased, along with increased IL-6.

The most significant changes in immunoreactivity and immunoresistance, as well as metabolic disorders, were found in patients of group II with hepatosplenomegaly against the background of persistence of herpesvirus infection. Metabolic disorders manifested in low content of the amino acids methionine in $45.5 \%$ of patients in this group and cysteine in 
$81.3 \%$. The innate immunity disorders in this group were characterized by high activity of $\mathrm{C} 3$ component and low activity of $\mathrm{C} 4$ component against the background of high level of ROS in neutrophils. Dysregulation in this immunity link in group II patients was accompanied by the formation of antineutrophil antibodies (ANCA) in $85.7 \%$ of patients, of which perinuclear antibodies (pANCA) to myeloperoxidase were detected in $71.4 \%$ of the examined patients, and cytoplasmic antibodies (cANCA) to proteinase 3 - in $14.3 \%$. The disequilibrium in the cytokines was also revealed in group II: high levels of IFN- $\gamma$, IL-1 $\beta$, TNF- $\alpha$, IL-18 and IL-6. Significant changes in various immunity links in patients with hepatosplenomegaly against the background of persistence of herpesvirus infection led to the formation of autoimmune reactions in $64.7 \%$ of patients, which was expressed in the formation of a wide range of antinuclear antibodies 11 specificities, including ANA to chromatin, chromatin-associated proteins, and to cytoskeleton.

In patients of group III, low content of neutrophils, which took part in phagocytosis with their insufficient absorption capacity, was revealed, as well as a high frequency of occurrence of antineutrophil antibodies pANCA and cANCA (in $67.5 \%$ of the examined). Changes in the cytokine status of patients in this group were characterized by low concentration of TNF- $\alpha$, which affects the coagulation and functioning of the endothelium, as well as decrease in defense mechanisms by weakening the synergism of TNF- $\alpha$ and IFN- $\gamma$.

Thus, the developed model of the stepwise change of immunological markers makes it possible to justify the choice of a complex targeted treatment, including antiviral and immunotropic therapy. Furthermore, one should consider that the ongoing treatment should be aimed at eliminating the primary causes of the disease.

The study was financed from the state budget within the framework of the research and development program "Investigate immunopathological parameters in splenomegaly and hypersplenism to justify different treatments" (State registration No 0118U006665, National Academy of Medical Sciences of Ukraine) of the Diagnostic laboratory with immunoenzyme and immunofluorescence analysis of State Institution Zaycev V. T. Institute of General and Urgent Surgery of National Academy of Medical Sciences of Ukraine.

\section{References}

Ahsan, H., Ali, A., \& Ali, R. (2003). Oxygen free radicals and systemic autoimmunity. Clinical and Experimental Immunology, 131(3), 398- 404.

Alimova, L. A., Begmanov, S. A., Nigmatov, N. N., \& Abidova, N. A. (2015). Nekotorye aspekty razvitiya infekcionno-allergicheskogo i toksicheskogo gepatita $\mathrm{i}$ cirroza pecheni [Some aspects of the development of infectious-allergic and toxic hepatitis and liver cirrhosis]. Bulletin of Novosibirsk State Pedagogical University, 5(1), 80-87 (in Russian).

Bedard, K., \& Krause, K.-H. (2007). The NOX family of ROS-generating NADPH oxidases: Physiology and pathophysiology. Physiological Reviews, 87(1), 245-313.

Bhasin, D. K., \& Malhi, N. J. S. (2002). Variceal bleeding and portal hypertension: Much to learn, much to explore. Endoscopy, 34(2), 119-128.

Borisov, A. E., \& Kashchenko, V. A. (2009). Cirroz pecheni i portal'naya gipertenziya [Cirrhosis of the liver and portal hypertension]. Sintez-Buk, Saint Petersburg (in Russian).

Box, H. C., Dawidzik, J. B., \& Budzinski, E. E. (2001). Free radical-induced double lesions in DNA. Free Radical Biology and Medicine, 31(7), 856-868.

Brilland, B., Garnier, A. S., Chevailler, A., Jeannin, P., Subra, J.-F., \& Augusto, J.-F. (2020). Complement alternative pathway in ANCA-associated vasculitis: Two decades from bench to bedside. Autoimmunity Review, 19(1), 102424.

Caballero, F., Fernandez, A., Matias, N., Martinez, L., Fucho, R., Elena, M., Caballeria, J., Morales, A., Fernandez-Checa, J., \& Garcia-Ruiz, C. (2010). Specific contribution of methionine and choline in nutritional nonalcoholic steatohepatitis: Impact on mitochondrial S-adenosyl-L-methionine and glutathione. The Journal of Biological Chemistry, 285(24), 18528-18536.

Cadet, J., Bellon, S., Berger, M., Bourdat, A.-G., Douki, T., Duarte, V., Frelon, S., Gasparutto, D., Muller, E., Ravanat, J.-L., \& Sauvago, S. (2002). Recent aspects of oxidative DNA damage: Guanine lesions, measurement and substrate specificity of DNA repair glycosylases. Biological Chemistry, 383(6), 933-943.

Cooke, M. S., Evans, M. D., Dizdaroglu, M., \& Lunec, J. (2003). Oxidative DNA damage: Mechanisms, mutation, and disease. The Journal of the Federation of American Societies for Experimental Biology, 17, 1195-1214.
De Oliveira, I. M. X., \& da Silva, R. S. U. (2019). Rheumatological manifestations associated with viral hepatitis B or C. Revista da Sociedade Brasileira de Medicina Tropical, 2, e20180407.

Dixit, K., \& Ali, R. (2001). Antigen binding characteristics of antibodies induced against nitric oxide modified plasmid DNA. Biochimica et Biophysica Acta, $1528(1), 1-8$

Elbim, C., Monceaux, V., Mueller, Y. M., Lewis, M. G., Francois, S., Diop, O., Akarid, K., Hurtrel, B., Gougerot-Pocidalo, M.-A., Levy, Y., Katsikis, P. D., \& Estaquier, J. (2008). Early divergence in neutrophil apoptosis between pathogenic and nonpathogenic simian immunodeficiency virus infections of nonhuman primates. Journal of Immunology, 181(12), 8613-8623.

Ellmark, P., Furebring, C., \& Borrebaeck, C. A. (2003). Pre-assembly of the extracellular domains of CD40 is not necessary for rescue of mouse B cells from antiimmunoglobulin M-induced apoptosis. Immunology, 108(4), 452-457.

Ferreira, C. R., \& Gahl, W. A. (2017). Lysosomal storage diseases. Translational Science of Rare Diseases, 2, 1-71.

Fischer, R., Baumert, T., \& Blum, H. E. (2007). Hepatitis C virus infection and apoptosis. World Journal of Gasitoenterology, 13, 4865-4872.

Gorchakov, A. M., Kruchinsky, N. G., Gorchakova, F. T., \& Korosteleva, I. V. (2003). Metod kompleksnoj ocenki fagocitarnoj aktivnosti nejtrofilov krovi [Method of comprehensive assessment of the phagocytic activity of blood neutrophils]. Institute of Environmental and Professional Pathology, Minsk (in Russian).

Grechanina, E. Y., Grechanina, Y. B., \& Goldfarb, I. G. (2004). Hromosomnyj polimorfizm i metabolicheskie narusheniya - prichinno-sledstvennye svyati [Chromosomal polymorphism and metabolic disorders - cause-and-effect relations]. Ultrasound Perinatal Diagnostics, 17, $38-43$ (in Russian).

Kanto, T. (2008). Virus associated innate immunity in liver. Frontiers in Bioscience, $13,6183-6192$.

Klimova, O. M., Kordon, T. I., Smachilo, R. M., Beloziorov, I. V., Bichenko, K. O., Merezhko, O. S., \& Kudrevich, O. M. (2019). Diferencial'na diagnostika i korekciya metabolichnih ta imunologichnih porushen' u hvorih z cirozom pechinki, uskladnenim gepatosplenomegalijeyu ta portal'noyu gipertenzijeyu [Differential diagnosis and correction of metabolic and immunological disorders in ailments with liver cirrhosis, accelerating hepatosplenomegaly and portal hypertension]. Actual Problems of Current Medicine, 41, 31-41 (in Russian).

Knight, R. A., \& Melino, G. (2011). Cell death in disease: From 2010 onwards. Cell Death and Disese, 2, e202.

Kolter, T., \& Sandhoff, K. (2005). Principles of lysosomal membrane digestion: Stimulation of sphingolipid degradation by sphingolipid activator proteins and anionic lysosomal lipids. Annual Review of Cell and Developmental Biology, 21, 81-103.

Lallemand-Breitenbach, V., \& de The, H. (2018). PML nuclear bodies: From architecture to function. Current Opinion in Cell Biology, 52, 154-161.

Lam, G. Y., Huang, J., \& Brumell, J. H. (2010). The many roles of NOX2 NADPH oxidase-derived ROS in immunity. Seminars in Immunopathology, 32(4), 415-430.

Lieber, C. S. (2002). S-adenosyl-L-methionine: its role in the treatment of liver disorders. The American Journal of Clinical Nutrition, 76(5), 1183-1187.

Lu, S. C., Ramani, K., Ou, X., Lin, M., Yu, V., Ko, K., Park, R., Bottiglieri, T., Tsukamoto, H., Kanel, G., French, S. W., Mato, J. M., Moats, R., \& Grant, E. (2009). S-adenosylmethionine in the chemoprevention and treatment of hepatocellular carcinoma in a rat model. Hepatology, 50, 462-471.

Nilsson, B., \& Nilsson, E. K. (2012). Complement diagnostics: Concepts, indications, and practical guidelines. Clinical and Developmental Immunology, 2012, 962702.

Panasiuk, A., Prokopowicz, D., Zak, J., \& Wysocka, J. (2003). Peripheral blood T, B, and NK cells in relation to histological hepatitis activity and fibrosis stage in chronic hepatitis C. Hepato-Gastroenterology, 50(49), 178-182.

Park, B. H., Fikrig, S. M., \& Smithwick, E. M. (1968). Infection and nitrobluetetrazolium reduction by neutrophils: A diagnostic acid. Lancet, 2, 532-534.

Phaniendra, A., Jestadi, D. B., \& Periyasamy, L. (2015). Free radicals: Properties, sources, targets, and their implication in various diseases. Indian Journal of Clinical Biochemistry, 30(1), 11-26.

Robinson, M. W., Harmon, C., \& O'Farrelly, C. (2016). Liver immunology and its role in inflammation and homeostasis. Cellular and Molecular Immunology, 13, 267-276.

Scherer, M., \& Stamminger, T. (2016). Emerging role of PML nuclear bodies in innate immune signaling. Journal of Virology, 90(13), 5850-5854.

Simpson, W. L., Hermann, G., \& Balwani, M. (2014). Imaging of gaucher disease. World Journal of Radiology, 6(9), 657-668.

Spiller, O. B., Morgan, B. P., Tufaro, F., \& Devine, D. V. (1996). Altered expression of host-encoded complement regulators on human cytomegalovirus-infected cells. European Journal of Immunology, 26(7), 1532-1538.

Tkachenko, O. Y., Lapin, S. V., Mazing, A. V., Totolian, \& Areg, A. (2020). Russkoyazychnaya adaptaciya mezhdunarodnoj nomenklatury tipov svecheniya yadra i citoplazmy kletki (ICAP) dlya standartizacii vyyavleniya antinuklearnogo faktora [Russian-speaking adaptation of the international no- 
menclature of luminance types of the nucleus and cell cytoplasm (ICAP) for standardization of antinuclear factor detection]. Medical Immunology, 22(6), 1195-1214 (in Russian).

Voitsekhovsky, V. V., \& Goborov, N. D. (2019). Cplenomegaliya v klinicheskoj praktike [Splenomegaly in clinical practice]. Amur Medical Journal, 2(26), 6177 (in Russian).
Zimran, A., Sorge, J., Gross, E., Kubitz, M., West, C., \& Beutler, E. (1990). A glucocerebrosidase fusion gene in gaucher disease. Implications for the molecular anatomy, pathogenesis, and diagnosis of this disorder. The Journal of Clinical Investigation, 85(1), 219-222. 